\title{
SYNTHESIS, BIOLOGICAL EVALUATION, AND DOCKING STUDY OF NOVEL 2-PHENYL-1- BENZOPYRAN-4-ONE DERIVATIVES - AS A POTENT CYCLOOXYGENASE-2 INHIBITOR
}

\author{
NATARAJAN KIRUTHIGA*, THANGAVELU PRABHA, CHELLAPPA SELVINTHANUJA, KULANDAIVEL SRINIVASAN, \\ THANGAVEL SIVAKUMAR
}

Department of Pharmaceutical Chemistry, Nandha College of Pharmacy, Koorapalayam Pirivu, Perundurai Road, Erode - 638 052, Tamil Nadu, India. Email: kiruthigagovindaraj@gmail.com

Received: 27 October 2018, Revised and Accepted: 20 November 2018

ABSTRACT

Objective: The inflammation and oxidative stress were related together in the generation of reactive oxygen species, which is responsible for the enhancement of inflammation associated with various chronic diseases.

Methods: The aim of this study is to synthezise and characterizes the flavones (2-phenyl-1-benzopyran-4-one) derivatives and analyzed by their docking hypothetical data as an effective anti-inflammatory mediator against cyclooxygenase-2 (COX-2) enzyme. Further, the evaluation of various in vitro antioxidant and anti-inflammatory studies was carried out.

Results: The 10 compounds were synthesized and characterized by ultraviolet, infrared, nuclear magnetic resonance, and mass spectroscopic techniques. The docking data results of these 10 flavones derivatives against COX-2 enzymes (Protein Data Bank ID: 3LN1) showed the binding energy ranging between $-5.53 \mathrm{kcal} / \mathrm{mol}$ and $-7.02 \mathrm{kcal} / \mathrm{mol}$ when compared with that of the standard diclofenac ( $-6.34 \mathrm{kcal} / \mathrm{mol}$ ). The in vitro studies suggest that the lipophilic character of the side chain donor, along with the hydroxyl substituted flavones found to have significant half maximal inhibitory concentration values.

Conclusion: Based on these in silico and in vitro evaluation results, these synthesized compounds could act as a promising inhibitor to target the COX2 enzyme. Hence, those compounds were effective in the management of chronic diseases by exhibits free radical scavenging and anti-inflammatory property.

Keywords: Flavone derivatives, Cyclooxygenase-2, Antioxidant, Anti-inflammatory, Molecular docking.

(C) 2019 The Authors. Published by Innovare Academic Sciences Pvt Ltd. This is an open access article under the CC BY license (http://creativecommons. org/licenses/by/4. 0/) DOI: http://dx.doi.org/10.22159/ajpcr.2019.v12i3.30466

\section{INTRODUCTION}

Bioflavonoids or flavonoids are polyphenolic compounds and broadly distributed in plants, which acts as a secondary metabolite to the plants. Many flavonoids have an excellent antioxidant property and play an important role in preventing the major diseases such as cardiac disorder, antidiabetic, and anticancer, which are mainly initiated by the development of oxidative stress [1,2]. Oxidative stress is an important factor in the origin of several diabetic, cancer, cardiovascular, and degenerative diseases [3]. The generation of reactive oxygen species (ROS) acts as a core in the development of inflammatory diseases due to host defense mechanism of polymorphonuclear neutrophils which leads to oxidation of protein (tyrosine phosphatase) responsible for the production of an inflammatory signal molecule such as peroxiredoxin 2 [4].

The relationship between the oxidative stress and inflammation was described in many articles in connection with this, for example, in a diabetic condition; the excess of oxidative damage was developed in hyperglycemia followed by tissue injury [5]. It was clearly predicted that increasing level of nitrite, malondialdehyde, and lipid peroxidation leads to decreasing the total antioxidant enzymes of diabetic rat [6]. It is also well established that the various anti-inflammatory drugs could act by blocking the production of pro-inflammatory prostaglandins through the inhibition of cyclooxygenase (COX) [7].

Naturally available polyphenolic phytochemical compounds had a capability in scavenging and suppression of ROS and regulate the antioxidant defenses as a safeguard [8,9]. Furthermore, it plays a key role in ruling the inflammatory cellular activities and also modulates the enzyme activities in arachidonic acid and arginine metabolism.
The molecular mechanisms behind the polyphenols were inhibition of enzyme coupled with COX2, inducible nitric oxide synthase (iNOS), nuclear factor-kappa B (NF- $\mathrm{B})$, activating protein-1 (AP-1), and stimulating the phase II antioxidant detoxifying enzymes, mitogenactivated protein kinase, protein kinase $\mathrm{C}$, and some associated factors $[10,11]$. It has been reported that flavonoids have strong antioxidant activities; it shows direct scavenging free radicals, suppression of pro-inflammatory cytokines through inhibition of ROS and nitric oxide, decreasing inflammatory genes including COXs and iNOS, upregulating antioxidant enzymes, and modulating transcription factors such as NF- $\mathrm{B}$ and $\mathrm{AP}-1$, and enhancing the nuclear factor erythroid 2-related factor 2 signaling pathway [12-15].

Based on the above concept, the two pharmacophores, namely 2-phenyl- 4H- chromen - 4- one (flavones) and hydroxy 2-phenyl-4H- chromen - 4- one (hydroxy flavones) with some electron withdrawing and donating groups were chosen to produce the target compounds. To reveal the theoretical binding pattern of the compounds with COX-2, a docking study analysis was carried out using AutoDock 4.2. software for finding its binding affinity toward the receptor protein COX-2 (prostaglandin synthase-2). In addition with this, the targeted compounds were subjected for the evaluation of in vitro antioxidant and anti-inflammatory properties, which could provide supportive evidence between in silico and in vitro pharmacological study.

\section{METHODS}

\section{Chemical and reagents}

The substituted acetophenones, aromatic aldehydes, hydrogen peroxide, aspirin, sodium dihydrogen phosphate, dimethyl sulfoxide (DMSO), 
dimethylformamide, and methanol were purchased from SRL Pvt., Ltd., Mumbai, Merck India, HiMedia Pvt. Ltd, Mumbai, and Loba chemicals, Cochin. All the chemicals in this synthesis were of AR and LR grade.

The melting point of the synthesized compounds was determined by an open capillary method using digital melting point apparatus. The purity and progress of reaction were monitored by thin-layer chromatography using the mobile phase as hexane:ethyl acetate (4:1). The spots were observed by the ultraviolet (UV) light and iodine fumes. The $\lambda$ max of the synthesized compounds was recorded on Shimadzu ultra-visible spectrophotometer. Fourier transform infrared spectrophotometer (FTIR) was recorded on Shimadzu FTIR in the range of $4000 \mathrm{~cm}^{-1}-400 \mathrm{~cm}^{1}$ using $\mathrm{KBr}$ pellet technique. Mass fragmentation for the synthesized compounds was recorded using JEOL gas chromatography (GC) mate GC-mass spectrometry (GC-MS) spectrometer. Proton nuclear magnetic resonance (NMR) spectra were recorded using BRUKER advance III - 500 MHz FT NMR Spectrometer using the solvent DMSO. Chemical shifts were recorded in parts per million and trimethylsilane as an internal standard.

\section{General procedure for the synthesis of flavones derivatives}

In the first step, chalcones were synthesized by condensation of an equimolar mixture of substituted acetophenone and substituted aromatic aldehyde in the presence of strong base under warm condition. In the second step, chalcones were cyclized to flavone in the presence of oxidizing agent hydrogen peroxide and strong base under the temperature between 50 and $70^{\circ} \mathrm{C}[16,17]$. The general scheme of the synthesis of flavones and the substitution patterns for the synthesized compounds F1-F5 and HF1-HF3 were mentioned in Fig. 1 and Table 1.

\section{Molecular modeling study}

AutoDock 4.2 was used to identify the binding modes of synthesized derivatives responsible for the activity to find the binding energies of these synthesized compounds in the active sites. The ligands were drawn using ChemDraw Ultra 10.0. The mol form of each ligand was converted to Protein Data Bank (PDB) format using Open Babel, before the submission for the docking. The preparation of the receptor was processed through downloading the crystal structure of enzyme COX2 complexed with a selective inhibitor, celecoxib (PDB ID: 3LN1) from PDB (http://www. rcsb.org/pdb). The PDB file was imported to Accelrys studio viewer where the receptor preparation module was used to prepare the protein. All the bound water molecules and heteroatom were removed from the complex, both polar and non-polar hydrogen were added, and three-dimensional structure of the protein was corrected.

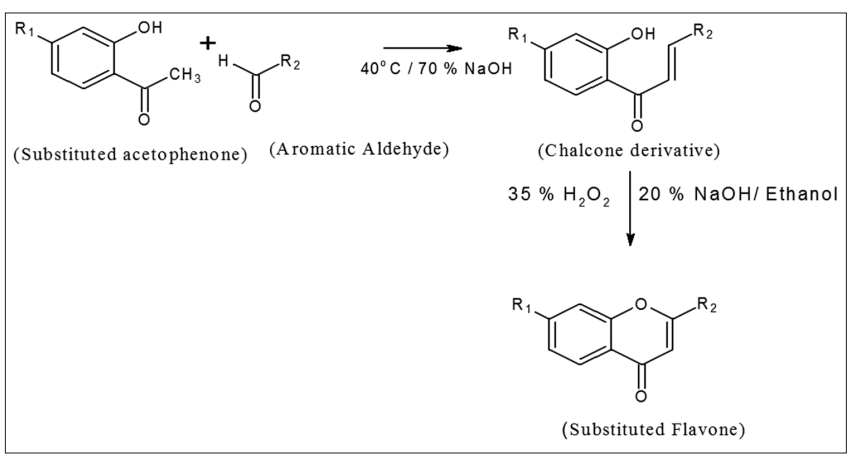

Fig. 1: General Synthetic scheme of flavones

Table 1: Substitution pattern of flavones derivatives

\begin{tabular}{llllll}
\hline Compound & $\mathbf{R}_{\mathbf{1}}$ & $\mathbf{R}_{\mathbf{2}}$ & Compound & $\mathbf{R}_{\mathbf{1}}$ & $\mathbf{R}_{\mathbf{2}}$ \\
\hline F1 & $-\mathrm{H}$ & $-\mathrm{C}_{6} \mathrm{H} 5$ & $\mathrm{~F} 5$ & $-\mathrm{H}$ & $-\mathrm{C}_{6} \mathrm{H}_{4}-\mathrm{CH}=\mathrm{CH}$ \\
F2 & $-\mathrm{H}$ & $-\mathrm{C}_{6} \mathrm{H}_{4}-2(\mathrm{Cl})$ & $\mathrm{F} 5_{\mathrm{b}}$ & $-\mathrm{H}$ & $-\mathrm{C}_{4} \mathrm{H}_{3} \mathrm{O}$ \\
F3 & $-\mathrm{H}$ & $-\mathrm{C}_{6} \mathrm{H}_{4}-4(\mathrm{Cl})$ & $\mathrm{HF} 1$ & $-\mathrm{OH}$ & $-\mathrm{C}_{6} \mathrm{H}_{4}-2(\mathrm{Cl})$ \\
F4 & $-\mathrm{H}$ & $-\mathrm{C}_{6} \mathrm{H}_{4}-4(\mathrm{~F})$ & $\mathrm{HF} 2$ & $-\mathrm{OH}$ & $-\mathrm{C}_{6} \mathrm{H}_{4}-4(\mathrm{Cl})$ \\
F5 & $-\mathrm{H}$ & $-\mathrm{C}_{6} \mathrm{H}_{4}-2\left(\mathrm{NO}_{2}\right)$ & $\mathrm{HF} 3$ & $-\mathrm{OH}$ & $-\mathrm{C}_{6} \mathrm{H}_{3}-2,4(\mathrm{Cl})$ \\
\hline
\end{tabular}

10 conformations were generated for each ligand. For the discussion of active compounds, the top-ranked conformation was considered.

\section{Evaluation of in vitro antioxidant activity}

All the synthesized flavones (F1-F5 and HF1-HF3) and the standard drug were prepared in the dose of $10,20,40,80$, and $160 \mu \mathrm{g} / \mathrm{ml}$, respectively, for performing the in vitro antioxidant activity.

\section{Reducing power ability method}

The sample of $2.5 \mathrm{ml}$ of $(1 \% \mathrm{w} / \mathrm{v})$ potassium ferric cyanide and $2.5 \mathrm{ml}$ of $0.2 \mathrm{M}$ phosphate buffer $(\mathrm{pH} 6.6$ ) were added to $1 \mathrm{ml}$ of various concentrations of the sample and standard (ascorbic acid), respectively $[18,19]$. The reaction mixtures were incubated at $50^{\circ} \mathrm{C}$ for $20 \mathrm{~min}$ followed by the addition of $2.5 \mathrm{ml}(10 \% \mathrm{w} / \mathrm{v})$ of trichloroacetic acid and centrifuged at $3000 \mathrm{rpm}$ for $10 \mathrm{~min}$, soon after $2.5 \mathrm{ml}$ of the supernatant was separated, mixed with $0.5 \mathrm{ml}(0.1 \% \mathrm{w} / \mathrm{v})$ of ferric chloride and $2.5 \mathrm{ml}$ of distilled water. The absorbance of the resulting solutions was measured at $700 \mathrm{~nm}$ against the blank

\section{Hydroxyl radical scavenging method}

About $1 \mathrm{ml}$ of iron-ethylenediaminetetraacetic acid (EDTA) solution, $0.5 \mathrm{ml}$ of $0.018 \%$ EDTA, $1 \mathrm{ml}$ of DMSO $(0.85 \%$ in $0.1 \mathrm{M} / \mathrm{l}$ phosphate buffer $\mathrm{pH} 7.4$ ), and $0.5 \mathrm{ml}$ of ascorbic acid were added to each sample and standard (gallic acid), respectively. The reaction mixtures were heated for $15 \mathrm{~min}$ at $80-90^{\circ} \mathrm{C}$ and $1 \mathrm{ml}$ of cold trichloroacetic acid (17.5\%) was added to terminate the reaction. After that, $3 \mathrm{ml}$ of Nash reagent $(75 \mathrm{~g}$ of ammonium acetate, $2 \mathrm{ml}$ of acetylacetone, and $3 \mathrm{ml}$ of glacial acetic acid) was added and incubated for $15 \mathrm{~min}$ at room temperature, and absorbance was measured at $412 \mathrm{~nm}$ using the blank [20].

\section{Nitric oxide scavenging assay method}

About $1 \mathrm{ml}$ of different concentration of synthesized flavones was added with $0.5 \mathrm{ml}$ of $5 \mathrm{mM}$ of sodium nitroprusside in phosphate buffered saline $\mathrm{pH} 7.4$ and incubated for $180 \mathrm{~min}$ at $25^{\circ} \mathrm{C}$. The reaction mixture was mixed with equal volume of Griess reagent ( $1 \%$ sulfanilamide and $0.1 \%$ naphthyl ethylenediamine dihydrochloride in $5 \%$ phosphoric acid), which results in color formation by diazotization of nitrite ions with naphthyl ethylenediamine dihydrochloride and sulfanilamide. The absorbance of chromophore was measured at $540 \mathrm{~nm}$ using blank [21]. The percentage inhibition of radical formation by the above methods was calculated by the following formula.

$\%$ Inhibition $=A_{c}-A_{t} / A_{c} \times 100 ;$ Where, $A_{t}=A b s o r b a n c e$ of test, $A=$ Absorbance of control.

\section{Evaluation of in vitro anti-inflammatory activity}

All synthesized flavones (F1-F5 $5_{\mathrm{b}}$ and HF1-HF3) and the standard drug were prepared in the dose of $10,20,40,80$, and $160 \mu \mathrm{g} / \mathrm{ml}$, respectively, for performing the anti-inflammatory activity.

\section{Denaturation of the protein albumin}

Respective concentrations of $2 \mathrm{ml}$ sample and standard (diclofenac) were added with $2.8 \mathrm{ml}$ of phosphate buffered saline ( $\mathrm{pH} \mathrm{6.4)}$ and mixed with egg albumin $(0.2 \mathrm{ml})$ taken from fresh hen's egg followed by incubation for $15 \mathrm{~min}$ at $27^{\circ} \mathrm{C}$. After incubation, the denaturation was produced by boiling the reaction mixture at $70^{\circ} \mathrm{C}$ for $10 \mathrm{~min}$, later was cooled and measured the absorbance of turbidity at $660 \mathrm{~nm}$ against blank [22].

\section{Membrane stabilizing activity}

The sheep blood was collected and mixed with the equal volume of sterilized Alsever's solution. The resulting solution was centrifuged at $3000 \mathrm{rpm}$ and separated the packed cells. Packed cells were washed with isosaline $(0.85 \%$ in $\mathrm{pH} 7.4$ ) and made $10 \% \mathrm{v} / \mathrm{v}$ suspension with isosaline. The $0.5 \mathrm{ml}$ red blood cell suspension was added with $2 \mathrm{ml}$ different concentration of synthesized flavones and the standard diclofenac. The $1 \mathrm{ml}$ of $0.15 \mathrm{M}$, pH 7.4 phosphate buffer, and $2 \mathrm{ml}$ of $0.36 \%$ of hyposaline were added and incubated for $30 \mathrm{~min}$ at room temperature followed by centrifugation at $3000 \mathrm{rpm}$. The supernatant 
liquid was separated and the hemoglobin content of that solution estimated at $560 \mathrm{~nm}$ against blank [23,24]. The percentage inhibition of radical formation and anti-inflammatory property was calculated by the following formula

$\%$ Inhibition $=A_{c}-A_{t} / A_{c} \times 100$; Where, $A_{t}=A b s o r b a n c e$ of test, $A=$ Absorbance of control

\section{Statistical analysis}

Experimental results were expressed as mean \pm standard error mean of three parallel measurements. Differences between control and test groups were tested for significance using one-way analysis of variance followed by Dunnett's t-test.

\section{RESULTS AND DISCUSSION}

\section{Synthesis and characterization of flavones}

The various derivatives of flavones were synthesized according to the protocol reported in the general scheme of synthesis. The percentage yields of the synthesized flavones were obtained moderately, and a melting point of those compounds was also recorded and presented uncorrected. The purity of the each synthesized compounds was determined by thin-layer chromatography. All the synthesized compounds were characterized by various spectroscopic techniques such as UV, IR, ${ }^{1} \mathrm{H}-\mathrm{NMR}$, and MS.

2-phenyl-4H-chromen-4-one (F1). $\quad \mathrm{MP}: \quad 130-132^{\circ} \mathrm{C} ; \quad \mathrm{R}_{\mathrm{f}}=0.56 ; \quad \%$ yield $=65.3 \% \mathrm{w} / \mathrm{w}$; UV $\lambda$ max: $\mathrm{CHCl}_{3}, \mathrm{~nm}: 297$; IR $(\mathrm{KBr} / \mathrm{cm}): 1739$ (lactone), 1643 (CO str.), 1585, 1550 (C=C Arom.str.), 1134, 1093 (COC str.), 771 (C-C bending); ${ }^{1} \mathrm{H}$ NMR (500 MHZ, DMSO): $\delta$ 7.4-7.9 (m, 8H, $\mathrm{ArH}), 6.9(\mathrm{~m}, 1 \mathrm{H}, \mathrm{ArH}) ; \mathrm{m} / \mathrm{z}: 222\left(\mathrm{M}^{+}\right), 120.7\left(\mathrm{C}_{7} \mathrm{H}_{6} \mathrm{O}_{2}\right)^{+}, 105.8\left(\mathrm{C}_{7} \mathrm{H}_{8}\right)^{+}$, $92.8\left(\mathrm{C}_{6} \mathrm{H}_{6} \mathrm{O}\right)^{+}, 77.9\left(\mathrm{C}_{6} \mathrm{H}_{5}\right)^{+}$.

3-(2-chlorophenyl)-4H-1-benzopyran-4-one (F2). MP: 157-160 ${ }^{\circ} \mathrm{C}$; $\mathrm{R}_{\mathrm{f}}=0.3 ; \%$ yield $=42.4 \% \mathrm{w} / \mathrm{w}$; UV $\lambda$ max: $\mathrm{CHCl}_{3}, \mathrm{~nm}: 241 ; \mathrm{IR}(\mathrm{KBr} / \mathrm{cm})$ : 1797 (lactone), 1687 (CO str.), 1593, 1564 (C=C Arom.str.), 1124, 1103, 1037 (COC str.), 754 (C-C bending); ${ }^{1} \mathrm{H}$ NMR (500 MHZ, DMSO): $\delta 6.6$ (m, 1H, ArH), 7.4-7.8 (m, 8H, ArH); m/z: $256\left(\mathrm{M}^{+}\right), 138.9\left(\mathrm{C}_{8} \mathrm{H}_{7} \mathrm{Cl}\right)^{+}, 120.9$ $\left(\mathrm{C}_{7} \mathrm{H}_{6} \mathrm{O}_{2}\right)^{+}, 91.9\left(\mathrm{C}_{6} \mathrm{H}_{5} \mathrm{O}\right), 77\left(\mathrm{C}_{6} \mathrm{H}_{5}\right)^{+}$

3-(4-chlorophenyl)-4H-1-benzopyran-4-one (F3). MP: $167-170^{\circ} \mathrm{C}$; $\mathrm{R}_{\mathrm{f}}=0.84 ; \%$ yield $=40.4 \% \mathrm{w} / \mathrm{w}$; UV $\lambda$ max: $\mathrm{CHCl}_{3}, \mathrm{~nm}: 261 ; \mathrm{IR}(\mathrm{KBr} / \mathrm{cm})$ 1735 (lactone), 1685 (CO str.), 1593, 1573 (C=C Arom.str.), 1130, 1091 (COC str.), 761 (C-C bending); ${ }^{1} \mathrm{H}$ NMR (500 MHZ, DMSO): $\delta$ 7.4-7.9 (m, 8H, ArH), $6.7(\mathrm{~m}, 1 \mathrm{H}, \mathrm{ArH}) ; \mathrm{m} / \mathrm{z}: 256\left(\mathrm{M}^{+}\right), 121.6\left(\mathrm{C}_{7} \mathrm{H}_{6} \mathrm{O}_{2}\right)^{+}, 139.5$ $\left(\mathrm{C}_{8} \mathrm{H}_{7} \mathrm{Cl}\right)^{+}, 76.6\left(\mathrm{C}_{6} \mathrm{H}_{5}\right)^{+}$.

2-(4-fluorophenyl)-4H-chromen-4-one (F4). MP: $241-243^{\circ} \mathrm{C} ; \mathrm{R}_{\mathrm{f}}=0.85$; $\%$ yield $=59.3 \% \mathrm{w} / \mathrm{w}$; UV $\lambda$ max: $\mathrm{CHCl}_{3}$, nm: 250; IR $(\mathrm{KBr} / \mathrm{cm}): 1772$ (lactone), 1685 (CO str.), 1577, 1514 (C=C Arom.str.), 1126, 1107, 1024 (COC str.), 773 (C-C bending); ${ }^{1} \mathrm{H}$ NMR (500 MHZ, DMSO): $\delta 6.9$ (m, $1 \mathrm{H}$, $\mathrm{ArH})$, 7.6-8.6 (m, 8H, ArH); m/z: 240( $\left.\mathrm{M}^{+}\right), 122\left(\mathrm{C}_{7} \mathrm{H}_{6} \mathrm{O}_{2}\right)^{+}, 119.5\left(\mathrm{C}_{8} \mathrm{H}_{6}\right.$ F) $)^{+}, 75.5\left(\mathrm{C}_{6} \mathrm{H}_{3}\right)^{+}$

3-(2-nitrophenyl)-4H-1-benzopyran-4-one (F5). MP: $\quad 145-148^{\circ} \mathrm{C}$; $\mathrm{R}_{\mathrm{f}}=0.43 ; \%$ yield $=51.6 \% \mathrm{w} / \mathrm{w}$; UV $\lambda$ max: DMSO, nm: 306; IR $(\mathrm{KBr} / \mathrm{cm})$ : 1797 (lactone), 1681 (CO str.), 1593, 1573 (C=C Arom.str.), 1128, 1091 (COC str.), 761 (C-C bending); ${ }^{1} \mathrm{H}$ NMR (500 MHZ, DMSO): $\delta$ 7.4-7.6 $(\mathrm{m}, 8 \mathrm{H}, \mathrm{ArH}), 6.2(\mathrm{~m}, 1 \mathrm{H}, \mathrm{ArH}) ; \mathrm{m} / \mathrm{z:} 267\left(\mathrm{M}^{+}\right), 121.1\left(\mathrm{C}_{7} \mathrm{H}_{6} \mathrm{O}_{2}\right)^{+}, 148.9$ $\left(\mathrm{C}_{8} \mathrm{H}_{7} \mathrm{NO}_{2}\right)^{+}, 76.9\left(\mathrm{C}_{6} \mathrm{H}_{5}\right)^{+}$.

2-[(Z)-2-phenylethenyl]-4H-chromen-4-one (F5). MP: $152-155^{\circ} \mathrm{C}$; $\mathrm{R}_{\mathrm{f}}=0.76 ; \%$ yield $=55.3 \% \mathrm{w} / \mathrm{w}$; UV $\lambda$ max: $\mathrm{CHCl}_{3}, \mathrm{~nm}: 299$; IR $(\mathrm{KBr} /$ cm): 1788 (lactone), 1699 (CO str.), 1583, 1554 (C=C Arom.str.), 1107, 1213 (COC str.), 769 (C-C bending), 3093 (C-H str.); ${ }^{1} \mathrm{H}$ NMR(500 MHZ, DMSO): $\delta 3.3$ (s, 1H), $6.8(\mathrm{~m}, 1 \mathrm{H}, \mathrm{ArH}), 7.3-7.8(\mathrm{~m}, 9 \mathrm{H}, \mathrm{ArH}) ; \mathrm{m} / \mathrm{z}: 248$ $\left(\mathrm{M}^{+}\right), 131\left(\mathrm{C}_{10} \mathrm{H}_{10} \mathrm{O}\right)^{+}, 121\left(\mathrm{C}_{7} \mathrm{H}_{6} \mathrm{O}_{2}\right)^{+}, 106\left(\mathrm{C}_{8} \mathrm{H}_{9}\right)^{+}, 78\left(\mathrm{C}_{6} \mathrm{H}_{5}\right)^{+}$.

2-(furan-2-yl)-4H-chromen-4-one (F5 ). MP: $\quad 164-168^{\circ} \mathrm{C} ; \quad \mathrm{R}_{\mathrm{f}}=0.48$; $\%$ yield $=50.4 \% \mathrm{w} / \mathrm{w}$; UV $\lambda$ max: $\mathrm{CH}_{3} \mathrm{OH}, \mathrm{nm}: 246$; IR $(\mathrm{KBr} / \mathrm{cm}): 1731$ (lactone), 1677 (CO str.), 1514, 1541 (C=C Arom.str.), 1024, 1137 (COC str.), 763 (C-C bending), 3058 (C-H str.); ${ }^{1} \mathrm{H}$ NMR(500 MHZ, DMSO): $\delta$ 6.8-6.9 (m, 1H, ArH), 7.1-7.5 (m, 7H, ArH); m/z: $213\left(\mathrm{M}^{+}\right), 92.5$ $\left(\mathrm{C}_{6} \mathrm{H}_{5} \mathrm{O}\right)^{+}, 122.4\left(\mathrm{C}_{7} \mathrm{H}_{6} \mathrm{O}_{2}\right)^{+}, 76.6\left(\mathrm{C}_{6} \mathrm{H}_{5}\right)^{+}$.

2-(2-chlorophenyl)-7-hydroxy-4H-chromen-4-one (HF1). MP: 172$175^{\circ} \mathrm{C} ; \mathrm{R}_{\mathrm{f}}=0.68 ; \%$ yield $=64.4 \% \mathrm{w} / \mathrm{w}$; UV $\lambda$ max: $\mathrm{CH}_{3} \mathrm{OH}, \mathrm{nm}$ : 358; IR (KBr/cm): 1701 (lactone), 1683 (CO str.), 1541, 1558 (C=C Arom.str.), 1020, 1218 (COC str.), 771 (C-C bending), 3033 (C-H str.), 3461 (OH str.); ${ }^{1} \mathrm{H}$ NMR(500 MHZ, DMSO): $\delta 6.6(\mathrm{~m}, 1 \mathrm{H}, \mathrm{ArH}), 7.4-7.9(\mathrm{~m}, 7 \mathrm{H}$, $\mathrm{ArH}), 9.4(\mathrm{~s}, 1 \mathrm{H}, \mathrm{OH}) ; \mathrm{m} / \mathrm{z}: 272\left(\mathrm{M}^{+}\right), 237.05\left(\mathrm{C}_{15} \mathrm{H}_{10} \mathrm{O}_{3}\right)^{+}, 138\left(\mathrm{C}_{7} \mathrm{H}_{6} \mathrm{O}_{3}\right)^{+}$, $103\left(\mathrm{C}_{8} \mathrm{H}_{7}\right)^{+}, 77.9\left(\mathrm{C}_{6} \mathrm{H}_{5}\right)^{+}$.

2-(4-chlorophenyl)-7-hydroxy-4H-chromen-4-one (HF2). MP: 182$184^{\circ} \mathrm{C} ; \mathrm{Rf}=0.52 ; \%$ yield $=69.3 \% \mathrm{w} / \mathrm{w}$; UV $\lambda$ max: $\mathrm{CH}_{3} \mathrm{OH}, \mathrm{nm}: 232 ; \mathrm{IR}$ (KBr/cm): 1789 (lactone), 1683 (CO str.), 1510, 1542 (C=C Arom.str.), 1095, 1130 (COC str.), 769 (C-C bending), 3080 (C-H str.), 3442 (OH str); ${ }^{1} \mathrm{H}$ NMR(500 MHZ, DMSO): $\delta 6.5$ (m, 1H, ArH), 7.5-7.9 (m, 7H, ArH), 9.5 (s, $1 \mathrm{H}, \mathrm{OH}) ; \mathrm{m} / \mathrm{z:} 272(\mathrm{~m}+1), 137\left(\mathrm{C}_{7} \mathrm{H}_{5} \mathrm{O}_{3}\right)^{+}, 104\left(\mathrm{C}_{8} \mathrm{H}_{8}\right)^{+}, 76.8\left(\mathrm{C}_{6} \mathrm{H}_{5}\right)^{+}$.

2-(2,4-dichlorophenyl)-7-hydroxy-4H-chromen-4-one (HF3). MP: $175-178^{\circ} \mathrm{C} ; \mathrm{R}_{\mathrm{f}}=0.81 ; \%$ yield $=55.6 \% \mathrm{w} / \mathrm{w}$; UV $\lambda$ max: $\mathrm{CH}_{3} \mathrm{OH}, \mathrm{nm}: 303$; IR ( $\mathrm{KBr} / \mathrm{cm}$ ): 1714 (lactone), 1649 (CO str.), 1510, 1541 (C=C Arom. str.), 1217, 1247 (COC str.), 771 (C-C bending), 3033 (C-H str.), 3479 (OH str); ; ${ }^{1} \mathrm{H}$ NMR(500 MHZ, DMSO): $\delta 6.6(\mathrm{~m}, 1 \mathrm{H}, \mathrm{ArH}), 7.3-7.9(\mathrm{~m}, 6 \mathrm{H}$, $\mathrm{ArH}), 9.4(\mathrm{~s}, 1 \mathrm{H}, \mathrm{OH}) ; \mathrm{m} / \mathrm{z}: 307\left(\mathrm{M}^{+}\right), 138.7\left(\mathrm{C}_{7} \mathrm{H}_{6} \mathrm{O}_{3}\right)^{+}, 172.4\left(\mathrm{C}_{8} \mathrm{H}_{6} \mathrm{Cl}_{2}\right)^{+}$, $123.6\left(\mathrm{C}_{7} \mathrm{H}_{6} \mathrm{O}_{2}\right), 76.7\left(\mathrm{C}_{6} \mathrm{H}_{5}\right)^{+}$.

\section{Molecular docking study}

The binding interactions of flavones toward the protein COX-2 (PDB ID: 3LN1) using docking studies by AutoDock 4.2. software [25,26] were revealed on the basis of structure-based design. The most favorable docking poses of the 10 docked conformations for each molecule were analyzed for further investigation of the ligand interactions within the active sites of the receptor. The wonderful number of interactions with the active site residues coupled with minimum favorable binding energy state. Hence, it was considered that these compounds may serve as an effective replacement agent for the anti-inflammatory drugs and thereby associated chronic disease.

All the synthesized compounds have a higher binding affinity with the receptors, in the narrow range of binding energy for the protein PDB ID: 3LN1 and showed the docking score value in the range of $-5.53--7.02 \mathrm{kcal} / \mathrm{mol}$ and this result suggests that few synthesized compounds showed a good docking score value, which is compared to that of reference drug diclofenac $(-6.34 \mathrm{kcal} / \mathrm{mol})$ (Table 2$)$

Among these 10 synthesized compounds, the best three compounds, namely F5, HF1, and HF3 were showed the best docking score and the interaction within the receptor, which was compared with standard diclofenac and visualized by the discovery studio (Fig. 2). Those compounds were studied for their electrostatic, hydrophobic bonding, and hydrogen bonding interactions on the receptor site, in which the compound HF1 showed their binding score $(-6.83 \mathrm{kcal} /$ $\mathrm{mol}$ ) and possess the alkyl/pi-alkyl interactions on lipophilic side chain substitution with Ile 484 and Phe 464 would help for the activity. In compound HF1, interactions over pi-cation on Lys 478 and for pi-donar hydrogen bond interaction with Phe 464 and Glu 465 on benzopyrone moiety were favourable for the pharmacological activity. Whereas the compound HF3 observed the highest binding score $(-7.02 \mathrm{kcal} / \mathrm{mol})$ and present within the binding pocket region forming conventional hydrogen bond and pi-cation interaction of benzopyrone ring with Lys 478 could favor the action. The alkyl/pi-alkyl interaction with the lipophilic side chain substitution along with the presence of hydroxyl group at position 7 shows stabilized interaction with basic amino acid residues Ile 484, Phe 464, Ala 474, and Lys 478.

\section{In vitro antioxidant activity}

The 10 synthesized flavones (F1-F5 and HF1-HF3) and its corresponding reference drug were evaluated for in vitro antioxidant 

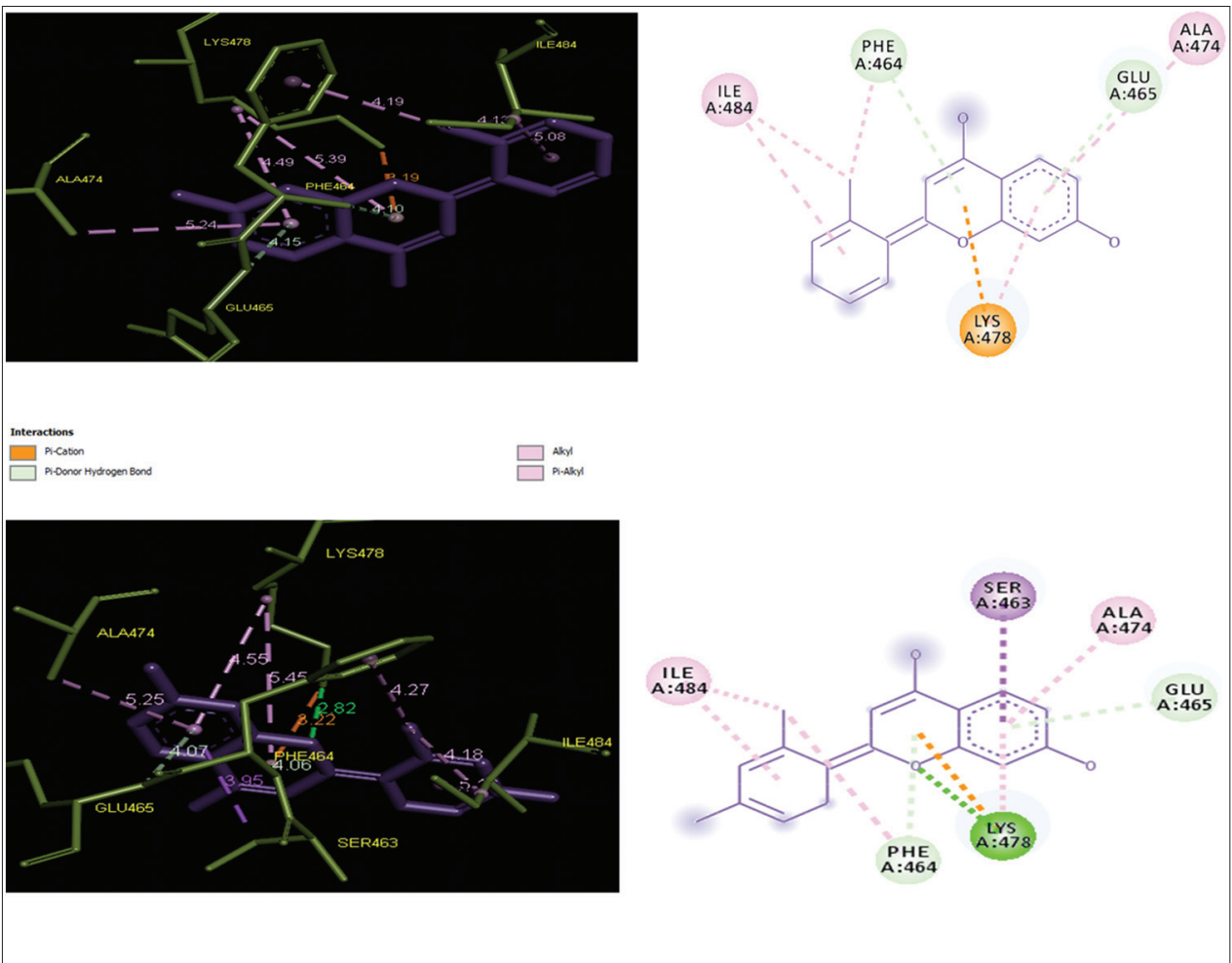

Fig. 2: Three-dimensional and two-dimensional structure of ligand-receptor interaction of the compounds HF1 and HF3, respectively, with PDB ID: 3LN1

Table 2: Best docking score of synthesized derivatives of flavones with - COX-2 (PDB ID: 3LN1)

\begin{tabular}{llll}
\hline $\begin{array}{l}\text { Compound } \\
\text { code }\end{array}$ & $\begin{array}{l}\text { Docking } \\
\text { score }\end{array}$ & $\begin{array}{l}\text { Compound } \\
\text { code }\end{array}$ & $\begin{array}{l}\text { Docking } \\
\text { score }\end{array}$ \\
\hline F1 & -6.45 & $\mathrm{~F}_{\mathrm{a}}$ & -6.26 \\
F2 & -5.53 & $\mathrm{F5}_{\mathrm{b}}$ & -5.52 \\
F3 & -5.96 & $\mathrm{HF} 1$ & -6.83 \\
F4 & -6.17 & $\mathrm{HF} 2$ & -6.33 \\
F5 & -6.69 & $\mathrm{HF} 3$ & -7.02 \\
\hline COX-2: Cyclooxygenase-2, PDB: Protein Data Bank &
\end{tabular}

studies and the results were shown for reducing power ability method (Table 3), hydroxyl radical scavenging method (Table 4), and nitric oxide radical scavenging assay (Table 5), respectively.

In reducing power assay method, the antioxidant compound has the ability to donate electron which neutralizes the free radicals. This is shown by conversion of the oxidized form of iron complex $\left(\mathrm{Fe}^{3+}\right)$ to the reduced form of ferrous complex $\left(\mathrm{Fe}^{2+}\right)$ which was indicated by Prussian blue color. Due to reducing power ability of synthesized flavones, the absorbance increases with increasing concentration. Among the all 10 synthesized flavones, the flavone with lipophilic in nature along with the presence of hydroxyl group, namely F2, F3, F4, HF1, HF2, and HF3 possess the noteworthy results when compared to that of the standard, (Table 3).

Hydroxyl radical is one of the free radical existed in our body, which is highly ROS responsible for attacking some of the substrates in our biological system such as carbohydrates, proteins, DNA, and polyunsaturated fatty acids. The ascorbic acid - Iron EDTA was responsible for the generation of hydroxyl radical in the presence of DMSO to form formaldehyde, which further converted into hydroxyl radicals. These radicals formation was identified by a nash reagent by the yellow colored complex formation. The optical density of this yellow color formation was decreased while increasing in the concentration of compounds. Due to the ability to donate proton toward the hydroxyl radical was retarded the formation of yellow color. By compared with the standard drug, the synthesized flavones with lipophilic side chain substitution along with hydroxyl substitution at their basic analog, namely F2, F3, F4, HF1, HF2, and HF3 have significantly inhibited the color formation by acting as an antioxidant (Table 4).

In general, nitric oxide radicals were generated in our body from the amino acid (L - arginine) which are present on our endothelial cells and phagocytes. These free radicals contain an unpaired electron which reacts with superoxide anion to form peroxynitrite (ONO.) $[27,28]$. These radicals were highly toxic and produced inflammation due to cellular damage results in juvenile diabetes, various sclerosis, ulcerative, arthritis, and so on [29]. Due to this reason, the present study deals with in vitro scavenging of nitric oxide assay of synthesised flavones in different concentrations. In this method, the sodium nitroprusside acts as a source for the generation of nitric oxide. This nitric oxide further reacts with the oxygen to form nitrite ions. Griess reagent contains sulfanilamide, which undergoes diazotization with nitrite ions and a forms diazonium salt, which couples with the naphthyl ethylene diamine to form a pink color complex. The scavenging of nitric oxide was directly related with decreasing of the optical density of pink color complex. Due to antioxidant property of synthesized compounds, which compete with oxygen interaction on nitric oxide to form the nitrite radicals, by which it retards the reaction along with Griess reagent to form the pink color. This clearly indicates that the concentration of the drug is inversely proportional to the absorbance [30]. As like the above methods, the percentage inhibition of the synthesized flavones with hydroxyl substitution (HF1 to HF3) was posses the significant result in scavenging of nitric oxide radicals by compared with the reference drug. The $\mathrm{IC}_{50}$ values of HF1, HF2, and HF3 showed significantly 38.0, 29.6, and $28.8 \mu \mathrm{g} / \mathrm{ml}$, respectively (Table 5).

\section{In vitro anti-inflammatory activity}

The generation of ROS may act as a hub in the development of inflammatory diseases due to the host defense mechanism which leads to oxidation of protein, which is responsible for the production of pro-inflammatory signals. On this concept, denaturation of protein is one of the well-documented causes of inflammation [31,32]. The anti- 
Table 3: Antioxidant effect of synthesized flavones by reducing power ability method

\begin{tabular}{|c|c|c|c|c|c|}
\hline \multirow[t]{2}{*}{ Compounds } & \multicolumn{5}{|l|}{ Absorbance } \\
\hline & $10 \mu \mathrm{g} / \mathrm{ml}$ & $20 \mu \mathrm{g} / \mathrm{ml}$ & $40 \mu \mathrm{g} / \mathrm{ml}$ & $80 \mu \mathrm{g} / \mathrm{ml}$ & $160 \mu \mathrm{g} / \mathrm{ml}$ \\
\hline F1 & $0.034 \pm 0.001$ & $0.046 \pm 0.002$ & $0.075 \pm 0.001$ & $0.126 \pm 0.007$ & $0.188 \pm 0.010$ \\
\hline F3 & $0.128 \pm 0.019$ & $0.342 \pm 0.011$ & $0.552 \pm 0.028$ & $0.695 \pm 0.050$ & $0.806 \pm 0.064$ \\
\hline F4 & $0.239 \pm 0.010$ & $0.388 \pm 0.021$ & $0.505 \pm 0.002$ & $0.631 \pm 0.060$ & $0.789 \pm 0.068$ \\
\hline F5 & $0.086 \pm 0.002$ & $0.126 \pm 0.009$ & $0.182 \pm 0.002$ & $0.258 \pm 0.012$ & $0.311 \pm 0.020$ \\
\hline $\mathrm{F} 5$ & $0.038 \pm 0.002$ & $0.096 \pm 0.002$ & $0.159 \pm 0.007$ & $0.208 \pm 0.019$ & $0.275 \pm 0.020$ \\
\hline $\mathrm{F} 5_{\mathrm{b}}^{\mathrm{a}}$ & $0.072 \pm 0.004$ & $0.155 \pm 0.008$ & $0.201 \pm 0.015$ & $0.289 \pm 0.024$ & $0.342 \pm 0.017$ \\
\hline HF1 & $0.278 \pm 0.014$ & $0.412 \pm 0.028$ & $0.596 \pm 0.034$ & $0.729 \pm 0.058$ & $0.874 \pm 0.07$ \\
\hline $\mathrm{HF} 2$ & $0.263 \pm 0.020$ & $0.390 \pm 0.014$ & $0.503 \pm 0.029$ & $0.624 \pm 0.042$ & $0.710 \pm 0.056$ \\
\hline HF3 & $0.321 \pm 0.016$ & $0.439 \pm 0.026$ & $0.561 \pm 0.031$ & $0.648 \pm 0.046$ & $0.733 \pm 0.049$ \\
\hline Ascorbic Acid & $0.361 \pm 0.018$ & $0.522 \pm 0.031$ & $0.669 \pm 0.046$ & $0.792 \pm 0.047$ & $0.923 \pm 0.055$ \\
\hline
\end{tabular}

All values are mean \pm SEM, $n=3$. One-way analysis of variance followed by Dunnett's test was performed as the test of significance. SEM: Standard error mean

Table 4: Antioxidant effect of synthesized flavones by hydroxyl radical scavenging assay

\begin{tabular}{|c|c|c|c|c|c|c|}
\hline \multirow[t]{2}{*}{ Compounds } & \multicolumn{6}{|c|}{ \% Hydroxyl radical scavenging assay } \\
\hline & $10 \mu \mathrm{g} / \mathrm{ml}$ & $20 \mu \mathrm{g} / \mathrm{ml}$ & $40 \mu \mathrm{g} / \mathrm{ml}$ & $80 \mu \mathrm{g} / \mathrm{ml}$ & $160 \mu \mathrm{g} / \mathrm{ml}$ & $\mathrm{IC}_{50}$ \\
\hline $\mathrm{F} 1$ & $9.87 \pm 0.69$ & $18.45 \pm 1.85$ & $30.55 \pm 3.18$ & $48.16 \pm 1.41$ & $65.62 \pm 1.8$ & 105.4 \\
\hline $\mathrm{F} 2$ & $14.86 \pm 0.94$ & $25.67 \pm 1.56$ & $39.63 \pm 2.74$ & $65.77 \pm 3.22$ & $74.05 \pm 3.62$ & 77.6 \\
\hline F3 & $9.01 \pm 0.72$ & $16.29 \pm 1.69$ & $29.51 \pm 1.72$ & $60.48 \pm 1.65$ & $72.31 \pm 3.39$ & 91.3 \\
\hline $\mathrm{F} 4$ & $10.49 \pm 0.62$ & $17.43 \pm 0.87$ & $38.86 \pm 1.61$ & $50.29 \pm 1.27$ & $66.01 \pm 3.02$ & 100 \\
\hline F5 & $6.89 \pm 0.44$ & $10.94 \pm 0.63$ & $16.4 \pm 1.55$ & $25.34 \pm 1.52$ & $32.12 \pm 2.91$ & - \\
\hline $\mathrm{F} 5$ & $6.93 \pm 0.36$ & $9.52 \pm 0.67$ & $16.58 \pm 1.18$ & $24.29 \pm 2.16$ & $36.3 \pm 1.44$ & - \\
\hline $\mathrm{F} 5_{\mathrm{b}}^{\mathrm{a}}$ & $7.82 \pm 0.88$ & $10.45 \pm 0.74$ & $17.02 \pm 1.25$ & $23.45 \pm 1.98$ & $30.85 \pm 0.98$ & - \\
\hline HF1 & $18.02 \pm 1.86$ & $35.53 \pm 3.03$ & $49.79 \pm 3.19$ & $71.01 \pm 4.18$ & $90.19 \pm 4.27$ & 55.4 \\
\hline HF2 & $13.22 \pm 1.09$ & $22.12 \pm 2.65$ & $48.67 \pm 2.98$ & $69.18 \pm 3.96$ & $88.74 \pm 4.18$ & 65.4 \\
\hline HF3 & $19.45 \pm 2.14$ & $30.75 \pm 2.92$ & $50.1 \pm 3.46$ & $72.85 \pm 4.41$ & $91.04 \pm 4.72$ & 55.9 \\
\hline Gallic acid & $21.96 \pm 1.63$ & $38.27 \pm 3.18$ & $55.69 \pm 3.54$ & $73.21 \pm 3.72$ & $95.57 \pm 4.67$ & 46.7 \\
\hline
\end{tabular}

All values are mean \pm SEM, $n=3$. One-way Analysis of Variance followed by Dunnett's test was performed as the test of significance. IC ${ }_{50}$ Half maximal inhibitory concentration. SEM: Standard error mean

Table 5: Antioxidant effect of synthesized flavones by nitric oxide scavenging assay

\begin{tabular}{|c|c|c|c|c|c|c|}
\hline \multirow[t]{2}{*}{ Compounds } & \multicolumn{6}{|c|}{$\%$ Inhibition of nitric oxide scavenging } \\
\hline & $10 \mu \mathrm{g} / \mathrm{ml}$ & $20 \mu \mathrm{g} / \mathrm{ml}$ & $40 \mu \mathrm{g} / \mathrm{ml}$ & $80 \mu \mathrm{g} / \mathrm{ml}$ & $160 \mu \mathrm{g} / \mathrm{ml}$ & $\mathrm{IC}_{50}$ \\
\hline $\mathrm{F} 1$ & $17.45 \pm 0.57$ & $23.57 \pm 0.49$ & $35.75 \pm 2.14$ & $42.24 \pm 2.96$ & $49.84 \pm 2.57$ & - \\
\hline F3 & $4.27 \pm 0.21$ & $9.96 \pm 0.58$ & $18.98 \pm 0.44$ & $25.94 \pm 1.36$ & $34.96 \pm 1.29$ & - \\
\hline $\mathrm{F} 4$ & $14.63 \pm 0.54$ & $25.17 \pm 1.45$ & $37.03 \pm 1.52$ & $49.84 \pm 2.41$ & $64.01 \pm 2.63$ & 101.2 \\
\hline F5 & $3.32 \pm 0.19$ & $8.54 \pm 0.33$ & $18.51 \pm 0.63$ & $24.36 \pm 1.35$ & $33.86 \pm 1.56$ & - \\
\hline F5a & $4.52 \pm 0.27$ & $7.59 \pm 0.36$ & $15.18 \pm 1.29$ & $22.15 \pm 1.32$ & $29.11 \pm 1.74$ & - \\
\hline $\mathrm{F} 5 \mathrm{~b}$ & $4.27 \pm 0.29$ & $9.96 \pm 0.69$ & $16.93 \pm 1.53$ & $22.62 \pm 1.38$ & $31.01 \pm 2.17$ & - \\
\hline HF1 & $30.53 \pm 1.83$ & $43.98 \pm 2.63$ & $57.43 \pm 2.39$ & $72.46 \pm 1.34$ & $87.02 \pm 2.22$ & 38.0 \\
\hline HF2 & $28.48 \pm 1.70$ & $43.03 \pm 2.16$ & $59.33 \pm 1.86$ & $74.05 \pm 2.44$ & $87.65 \pm 2.25$ & 38.2 \\
\hline HF3 & $26.4 \pm 1.55$ & $44.24 \pm 1.92$ & $59.8 \pm 2.45$ & $74.36 \pm 2.29$ & $86.52 \pm 2.73$ & 38.7 \\
\hline Gallic Acid & $32.27 \pm 1.93$ & $45.25 \pm 2.46$ & $62.34 \pm 1.74$ & $80.22 \pm 2.56$ & $98.1 \pm 2.88$ & 28.8 \\
\hline
\end{tabular}

All values are mean \pm SEM, $n=3$. One-way Analysis of Variance followed by Dunnett's test was performed as the test of significance. IC ${ }_{50}$ Half maximal inhibitory concentration. SEM: Standard error mean

inflammatory drugs, for example, salicylic acid and phenylbutazone had shown dose-dependent ability to prevent thermally induced protein denaturation. The denaturation is used loosely to designate the change of proteins from a soluble to an insoluble form brought about by a large variety of chemical and physical agents including acids, alkalies, alcohol, acetone, salts of heavy metals, dyes, heat, light, and pressure. On the other hand, the hemolytic effect of hypotonic solution related to the excessive accumulation of fluid within the cell resulting in the rupturing of $\mathrm{RBC}$ membrane. Due to this reason, the RBC was more susceptible to secondary damage through free radicalinduced lipid peroxidation. Hence, the membrane stabilization helpful in the prevention of leakage of serum protein and fluids into the tissues during increased permeability caused by the inflammatory mediators.
The results showed that the synthetic flavones which perhaps the stabilized RBC membrane by preventing the release of lytic enzymes and active mediators of inflammation.

Inflammation is a biological response toward the tissue injury or damage along with infection, which is probably due to heat, pain, redness, swelling, and some abnormal physiological activities. The cellular damage or injury occurs due to microbial agents or chemical substances or by physical trauma. In these conditions, the chemical mediators are released from the injured tissues to disturb the tissue repair [33]. Due to this reason, nonsteroidal anti-inflammatory drugs (NSAID's) are administered for the management of inflammation, but those are produced gastric irritation leads to the formation of gastric 
Table 6: Percentage inhibition of synthesised flavones on protein denaturation

\begin{tabular}{|c|c|c|c|c|c|c|}
\hline \multirow[t]{2}{*}{ Compounds } & \multicolumn{5}{|c|}{$\%$ Inhibition of denaturation of the protein } & \multirow[t]{2}{*}{$\mathrm{IC}_{50}$ Values $(\mu \mathrm{g} / \mathrm{ml})$} \\
\hline & $10(\mu \mathrm{g} / \mathrm{ml})$ & $20(\mu \mathrm{g} / \mathrm{ml})$ & $40(\mu \mathrm{g} / \mathrm{ml})$ & $80(\mu \mathrm{g} / \mathrm{ml})$ & $160(\mu \mathrm{g} / \mathrm{ml})$ & \\
\hline F1 & $11.70 \pm 0.42$ & $19.24 \pm 1.42$ & $26.95 \pm 1.52$ & $35.53 \pm 2.08$ & $41.07 \pm 2.11$ & - \\
\hline F3 & $23.07 \pm 1.15$ & $34.69 \pm 1.72$ & $45.53 \pm 2.27$ & $55.50 \pm 2.82$ & $65.74 \pm 3.11$ & 82.1 \\
\hline F4 & $28.36 \pm 0.92$ & $39.02 \pm 2.31$ & $48.74 \pm 2.48$ & $60.36 \pm 3.93$ & $72.85 \pm 3.88$ & 62.6 \\
\hline F5 & $14.39 \pm 0.74$ & $24.45 \pm 1.46$ & $36.34 \pm 1.63$ & $47.26 \pm 2.13$ & $54.81 \pm 2.35$ & 121.4 \\
\hline F5 & $13.79 \pm 0.77$ & $20.38 \pm 1.16$ & $26.01 \pm 1.22$ & $32.09 \pm 2.53$ & $45.62 \pm 2.15$ & - \\
\hline $\mathrm{F} 5_{\mathrm{b}}^{\mathrm{a}}$ & $14.39 \pm 0.46$ & $20.90 \pm 1.24$ & $30.24 \pm 1.62$ & $36.16 \pm 2.74$ & $42.49 \pm 2.91$ & - \\
\hline HF1 & $26.01 \pm 1.28$ & $40.32 \pm 2.46$ & $55.07 \pm 3.34$ & $66.60 \pm 3.55$ & $80.39 \pm 4.76$ & 50.8 \\
\hline HF2 & $26.88 \pm 3.54$ & $45.52 \pm 2.97$ & $64.74 \pm 3.82$ & $81.80 \pm 4.54$ & $95.16 \pm 4.28$ & 30.5 \\
\hline HF3 & $28.44 \pm 0.85$ & $39.98 \pm 2.53$ & $54.55 \pm 2.96$ & $73.54 \pm 4.12$ & $84.12 \pm 3.88$ & 44.7 \\
\hline Std & $27.22 \pm 0.94$ & $45.28 \pm 2.05$ & $65.5 \pm 2.57$ & $82.63 \pm 3.18$ & $97.54 \pm 2.94$ & 29.7 \\
\hline
\end{tabular}

All values are mean \pm SEM, $n=3$. One-way Analysis of Variance followed by Dunnett's test was performed as the test of significance. IC ${ }_{50}$ Half maximal inhibitory concentration

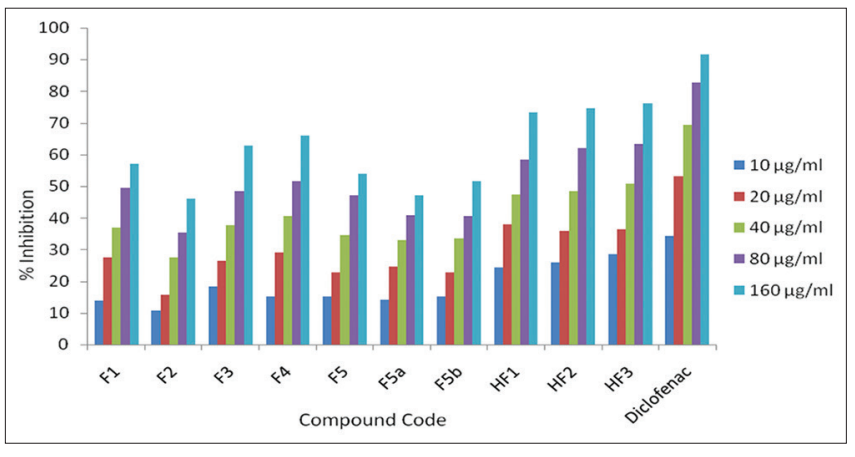

Fig. 3: Percentage Inhibition of hemolysis of synthesized flavones. All values are mean \pm standard error mean, $n=3$. One-way analysis of variance followed by Dunnett's test was performed as the test of significance

ulcer [34]. Natural products are our traditional medicines which are used to overcome the adverse effects in the development of the modern medical field.

Hence, in the present study, the naturally mimicking synthesized compounds were evaluated for in vitro anti-inflammatory activity by denaturation of protein and membrane stabilizing activity. Protein denaturation is one of the common causes during rheumatoid arthritis $[35,36]$. Therefore, the synthesized flavones which prevent the denaturation of protein would be a potent anti-inflammatory drug. Thus, the drug effective against the protein denaturation is a common mechanism [31] before evaluating the inhibitory effect of COX [32].

One of the common methods for evaluation of in vitro antiinflammatory activity was a membrane stabilizing method. In this method, hypotonicity was induced for lysis of erythrocytes which explored by our synthesized flavones due to the well-stabilizing effect of erythrocytes. Lysosome membrane stabilization was important for inflammatory response, by overcoming the leakage of constituents inside the lysosomes such as neutrophils, protease, and bactericidal enzymes. Those were highly toxic in the development of inflammation and lead to tissue damage [37]. By which, stabilization of membrane was an important factor for NSAIDs as an anti-inflammatory effect. Hence, the synthesized flavones (F2, F3, F4, HF1, HF2, and HF3) were possess the significant result by the protection of membrane stabilization through hypotonicity induced lysis (Table 6).

Based on this fact, the percentage inhibition of protein denaturation and hemolysis (Table 6 and Fig. 3) by synthesized flavones was increases by increasing concentration when compared with the standard. The synthesized flavones with hydroxyl substitution (HF1-HF3) showed the significant $\mathrm{IC}_{50}$ values.

\section{CONCLUSION}

The study deals with the synthesis and characterization of flavones by various spectroscopic techniques. An in silico docking studies of the 10 target molecules with COX-2 enzyme results showed that the best docking score was obtained for the target molecules are in the range of $-5.35-7.02 \mathrm{kcal} / \mathrm{mol}$. This effect is payable to the presence of hydroxyl group in 2-phenyl-1-benzopyran-4-one moiety with its structure. On docking study results, it was quite understood that all the basic analog of this synthesized compounds showed a best target protein interaction, which was further confirmed by its least binding score. These synthetic compounds were subjected for in vitro antioxidant and antiinflammatory activity. Based on the results, the synthesized flavones with lipophilic side chain donor atom at the side chain substitution also with a hydroxyl group at position 7 of flavones moiety, namely F2, F3, F4, HF1, HF2, and HF3 were showed the significant scavenging effect on free radicals and inhibition of inflammation process when compared with a standard drug. Thus, this study concluded that the synthesized flavones especially with hydroxyl substitution along with 2-chloro, 4-chloro, and 2,4-dichloro groups were possess a great efficacy in antiinflammatory activity and act as an anti-proinflammatory mediator. In evidence with the available literature, the anti-inflammatory property depends on the lipophilicity character of the flavones derivatives, which promotes the binding interaction with COX-2.

\section{AUTHORS' CONTRIBUTION}

All authors have an equal contribution for this article workup.

\section{CONFLICTS OF INTEREST}

The authors declare no conflicts of interest.

\section{REFERENCES}

1. Houstis N, Rosen ED, Lander ES. Reactive oxygen species have a causal role in multiple forms of insulin resistance. Nature 2006;440:944-8.

2. Rahimi R, Nikfar S, Larijani B, Abdollahi M. A review on the role of antioxidants in the management of diabetes and its complications. Biomed Pharmacother 2005;59:365-73.

3. Asma M, Hamama B, Meziti H, Seoussen K, Abderrahmane S, Ibrahim D. Antioxidant and anti-inflammatory activities of Rubus fruticosus and Zizyphus vulgaris methanol extracts. Int J Pharm Pharm Sci 2017;9:69-76.

4. Salzano S, Checconi P, Hanschmann EM, Lillig CH, Bowler LD, $\mathrm{Chan} \mathrm{P}$, et al. Linkage of inflammation and oxidative stress via release of glutathionylated peroxiredoxin-2, which acts as a danger signal. Proc Natl Acad Sci U S A 2014;111:12157-62.

5. Reagan LP, Magariños AM, McEwen BS. Neurological changes induced by stress in streptozotocin diabetic rats. Ann N Y Acad Sci 1999;893:126-37.

6. Acar A, Akil E, Alp H, Evliyaoglu O, Kibrisli E, Inal A, et al. Oxidative damage is ameliorated by curcumin treatment in brain and sciatic nerve of diabetic rats. Int J Neurosci 2012;122:367-72. 
7. Steinmeyer J. Pharmacological basis for the therapy of pain and inflammation with nonsteroidal anti-inflammatory drugs. Arthritis Res 2000;2:379-85.

8. Mishra A, Sharma AK, Kumar S, Saxena AK, Pandey AK. Bauhinia variegata leaf extracts exhibit considerable antibacterial, antioxidant, and anticancer activities. Biomed Res Int 2013;2013:915436.

9. Kumar S, Sharma UK, Sharma AK, Pandey AK. Protective efficacy of Solanum xanthocarpum root extracts against free radical damage: Phytochemical analysis and antioxidant effect. Cell Mol Biol (Noisyle-grand) 2012;58:174-81.

10. Santangelo C, Varì R, Scazzocchio B, Di Benedetto R, Filesi C, Masella R, et al. Polyphenols, intracellular signalling and inflammation. Ann Ist Super Sanita 2007;43:394-405.

11. Kim YS, Young MR, Bobe G, Colburn NH, Milner JA. Bioactive food components, inflammatory targets, and cancer prevention. Cancer Prev Res (Phila) 2009;2:200-8.

12. Nagle DG, Ferreira D, Zhou YD. Epigallocatechin-3-gallate (EGCG): Chemical and biomedical perspectives. Phytochemistry 2006;67:1849-55.

13. Park SA, Choi MS, Jung UJ, Kim MJ, Kim DJ, Park HM, et al. Eucommia ulmoides oliver leaf extract increases endogenous antioxidant activity in Type 2 diabetic mice. J Med Food 2006;9:474-9

14. Tuñón MJ, García-Mediavilla MV, Sánchez-Campos S, GonzálezGallego J. Potential of flavonoids as anti-inflammatory agents: Modulation of pro-inflammatory gene expression and signal transduction pathways. Curr Drug Metab 2009;10:256-71.

15. Ribeiro D, Freitas M, Lima JL, Fernandes E. Proinflammatory pathways: The modulation by flavonoids. Med Res Rev 2015;35:877-936.

16. Cole AL, Hossain S, Cole AM, Phanstiel O $4^{\text {th }}$. Synthesis and bioevaluation of substituted chalcones, coumaranones and other flavonoids as anti-HIV agents. Bioorg Med Chem 2016;24:2768-76.

17. Pramod S, Dasharath D, Ravi V, Pudukulathan K, Cyclization of 2'-hydroxychalcones to flavones using ammonium iodide as an iodine source-an eco-friendly approach. J Serb Chem Soc 2013;78:909-16.

18. Ammar T, Ruplal Choudhary C. Determination of antioxidant activity in different kinds of plants in-Vivo and in-Vitro by using diverse technical methods. J Nutr Food Sci 2013;3:1-9.

19. Zhao H, Fan W, Dong J, Lu J, Chen J, Fan W, et al. Evaluation of antioxidant activities and total phenolic contents of typical malting barley varieties. Food Chem 2008;107:296-304

20. Klein SM, Cohen G, Cederbaum AI. Production of formaldehyde during metabolism of dimethyl sulfoxide by hydroxyl radical generating systems. Biochemistry 1981;20:6006-12.

21. Marcocci L, Maguire JJ, Droy-Lefaix MT, Packer L. The nitric oxidescavenging properties of Ginkgo biloba extract EGb 761. Biochem Biophys Res Commun 1994;201:748-55.

22. Alhakmani F, Khan SA, Ahmad A. Determination of total phenolic, in-vitro antioxidant and anti-inflammatory activity of seeds and fruits of Zizyphus spina-Christi grown in Oman. Asian Pac J Trop Biomed 2014;4:656-60

23. Shinde UA, Phadke AS, Nair AM, Mugantiwar AA, Dikshit VJ,
Saraf VO. Membrane stabilizing activity-a possible mechanism of action for the anti-inflammatory activity of Cedrus deodara wood oil. Fitoterapia 1999;70:251-7.

24. Gandhidasan R, Thamaraichelvan A. Antiinflamattory action of Lanea coromondelica by HRBC membarane stabilisation. Fitotherapia 1991;62:82-3.

25. Abdellatif KR, Chowdhury MA, Dong Y, Velázquez C, Das D, Suresh MR, et al. Diazen-1-ium-1,2-diolated nitric oxide donor ester prodrugs of 5-(4-hydroxymethylphenyl)-1-(4-aminosulfonylphenyl)3-trifluoromethyl-1H-pyrazole and its methanesulfonyl analog: Synthesis, biological evaluation and nitric oxide release studies. Bioorg Med Chem 2008;16:9694-8.

26. Abdellatif KR, Chowdhury MA, Dong Y, Das D, Yu G, Velázquez C, et al. Diazen-1-ium-1,2-diolated nitric oxide donor ester prodrugs of 5-(4-carboxymethylphenyl)-1-(4-methanesulfonylphenyl)-3trifluoromethyl-1H-pyrazole and its aminosulfonyl analog: Synthesis, biological evaluation and nitric oxide release studies. Bioorg Med Chem 2009; 17:5182-8

27. Nagmoti DM, Khatri DK, Juvekar PR, Juvekar AR. Antioxidant activity and free radical-scavenging potential of Pithecellobium dulce Benth seed extracts. Free Radic Antioxid 2011;2:37-43.

28. Prapurnachandra Y, Viswanathswamy AH. In-vitro Antioxidant and cytotoxic activity of rutin and piperine and their synergistic effect. Int $\mathrm{J}$ Pharm Pharm Sci 2016;8:78-82.

29. Taylor BS, Kim YM, Wang Q, Shapiro RA, Billiar TR, Geller DA, et al. Nitric oxide down-regulates hepatocyte-inducible nitric oxide synthase gene expression. Arch Surg 1997;132:1177-83

30. Turkoglu A, Duru ME, Mercan N, Kivrak I, Gezer K. Antioxidant and antimicrobial activities of Laetiporus sulphurous (Bull) Murrill. Food Chem 2007; 101:267-73

31. Mizushima Y, Kobayashi M. Interaction of anti-inflammatory drugs with serum proteins, especially with some biologically active proteins. J Pharm Pharmacol 1968;20:169-73.

32. Vane JR. Inhibition of prostaglandin synthesis as a mechanism of action for aspirin-like drugs. Nat New Biol 1971;231:232-5.

33. Anonymous. New Medical Dictionary. New Delhi: Oxford and IBH Publishing Co. Pvt. Ltd.; 2007. p. 376.

34. Tripathi KD. Essentials of Medical Pharmacology. New Delhi: Jaypee Brothers Medical Publishers Ltd.; 2008. p. 189.

35. Opie EL. On the relation of necrosis and inflammation to denaturation of proteins. J Exp Med 1962;115:597-608.

36. Umapathy E, Ndebia EJ, Meeme A, Adam B, Menziwa P, NkehChungag $\mathrm{BN}$, et al. An experimental evaluation of Albuca setosa aqueous extract on membrane stabilization, protein denaturation and white blood cell migration during acute inflammation. J Med Plants Res 2010;4:789-95

37. Murugesh N, Vembar S, Damodaran C. Studies on erythrocyte membrane IV: In vitro haemolytic activity of oleander extract. Toxicol Lett 1981;8:33-8. 